\title{
The Politics of Juvenile Justice: Then and Now
}

\section{Barry Krisberg}

John R. Surton, Stubbom Children: Controlling Delinquency in the United States 1640-1981. Berkeley: University of California Press, 1988. Pp. $\mathrm{xii}+299$. $\$ 37.50$.

IRA M. SchwARTZ, (In)Justice for Juveniles: Rethinking the Best Interest of the Child. Lexington, Mass.: Lexington Books, 1989. Pp. xviii +184. $\$ 17.95$ cloth; $\$ 14.95$ paper.

Legal scholar Roscoe Pound illustrated the ambivalent response to our separate system of justice for juveniles. In 1957, Pound declared that American juvenile courts were "the greatest step forward in Anglo-American Law since the Magna Carta." However, Pound also worried that the virtually unlimited powers of the children's court could make it resemble Star Chamber proceedings. Some of this ambivalence reflects contradictory sentiments about children. While countless voices celebrate our love of children and their importance for the future, one must recall W. C. Fields's famous line that "anyone who hates children and dogs can't be all bad."

Fascination with juvenile misconduct and control has produced a rich and varied literature. There are excellent collections of primary source materials, most notably Robert Bremner (ed.), Children and Youth in America: A Documentary History ${ }^{1}$ and Wiley B. Sanders, Juvenile Offenders for A Thousand Years. ${ }^{2}$ Historians such as Mennel, Rothman, Pickett, and

Barry Krisberg is President of the National Council on Crime and Delinquency. Ph.D. 1971, University of Pennsylvania.

1. Robert Bremner (ed.), Children and Youth in America: A Documentary History (Cambridge, Mass.: Harvard University Press, 1970).

2. Wiley B. Sanders (ed.), Juvenile Offenders for a Thousand Years (Chapel Hill: University of North Carolina Press, 1970).

(c) 1991 American Bar Foundation.

0897-6546/90/1504-0893\$01.00 
Schlossman have written detailed analyses of the rise of the juvenile justice system. There are even provocative historical revisionists such as Platt and Liazos.

Two recent books substantially contribute to our knowledge of the political context and emergence of juvenile justice policies. The first, John R. Sutton's Stubborn Children, is a challenging scholarly work that shows theoretical depth and methodological sophistication, despite the use of substantial jargon. The second, Ira M. Schwartz's (In)Justice for Juveniles, is an insider's account of the politics of juvenile reform over the past two decades. In the words of the paperback advertisements, it is a "page-turner." This essay is a tale of these two books and their relevance for contemporary reformers.

\section{THE HISTORICAL CONTEXT OF JUVENILE JUSTICE POLITICS}

In Stubborn Children John Sutton examines the crises and negotiations that led to the development of juvenile justice and the structural factors leading the diffusion of legal changes to control wayward youths. He seeks to account for developments in the control of delinquents from the Massachusetts Stubborn Child Law of 1646 up until the early 1980s, an ambitious task of historical scope and coverage.

Sutton rejects the major theoretical orientations that have dominated thinking on the history of juvenile justice: the traditional view that juvenile justice practices have evolved as a steady march of progress toward more enlightened and humane treatment of children; the Marxian notion that juvenile justice control systems grew directly out of the ruling class's needs to manage the threats from the underside of society; and the thesis that reform is primarily the product of individual or agency conflicts over turf and bureaucratic power. Stubborn Children presents intriguing, if not compelling, evidence that a more complex explanatory model is required.

Sutton's book is an exercise in theory building, relying almost exclusively on well-known historical accounts of the legal developments reviewed. The theory development is grounded in an erudite knowledge of sociological theory. The empirical materials covered show Sutton's obvious command of the previous historical research, and his efforts to model the diffusion of laws employ innovative and sophisticated multivariate statistical models that are becoming part of the modern historian's repertoire. To his credit, Sutton ensures that the reader understands something of the broader societal issues in which each juvenile justice reform is played out.

The book continues a tradition, associated with Columbia University historian David Rothman, which focuses on the ideals and rhetoric of re- 
formers. ${ }^{3}$ Sutton is essentially providing a theory to explain transformations in ideology. He readily admits that changing ideological views may not be perfectly related to changing practices. In fact, Sutton makes a strong case that the actual practice of juvenile justice is remarkably static despite all the rhetorical warfare. Because of the focus on ideology, Sutton's is a "top-down" history that gives no significant role to ordinary people in the struggles to change social institutions. To my thinking this is a major weakness that undercuts the utility of the study for contemporary reform efforts.

The first reform epoch selected by Sutton is the enactment of the Stubborn Child Act of 1646. This law imposed the death penalty for children over the age of 16 years who chronically defy parental attempts to control their behavior. Despite the harshness of its wording, the law was rarely if ever applied except in the context of master-slave relationships. Yet, the Stubborn Child Act is interesting because it appears to be the first instance in which the authority of the state is injected into family matters. In fact, Sutton shows us that Puritan society was moving steadily toward greater centralized control over the conduct of its residents. For Sutton, the integration of family and societal control in one institutionthe family - was an outgrowth of ideological conflict and accommodation among various religious philosophies. Sutton diminishes the importance of economic or functional arguments to explain the early expansion of state control of children. However, a broader review of historical data suggests a more important role for economic and political considerations as well as theological ones.

The Puritans brought their children with them and from the outset made provisions for the care and control of young people. The Puritans sought to establish a religious community to serve God's Will in the New World. The Stubborn Child Act was focused on this religious agenda; it did not cover issues relating to Native American children or slaves.

In other colonies, especially in the South, settlement was defined by economic considerations. Most youths were either African slaves, Native American children, or lower-class European youngsters who were indentured into service for a specified period of time. The child control systems varied depending upon the types of youths being managed. For example, Native American children were often kidnapped and trained in the language and religion of the colonists. Early efforts to enslave Native Americans were not successful. Relations between European colonists and Native Americans centered on trading and securing of land rights.

3. David Rothman's works include Conscience and Convenience: The Asylum and its Altematives in Progressive America (1980); Doing Good: The Limits of Benevolence (1978); and The Discovery of the Asylum: Social Order and Disorder in the New Republic (1971), all published by Little, Brown \& Co., Boston. 
Spreading the gospel was a convenient rationale for the conquest of lands and people. Equally important was the financial incentive to recruit a friendly cadre to assist in negotiations and pacification programs among native peoples. Early Indian schools emphasized Bible study, worship, and work discipline. Despite flowery pronouncements, these schools resembled penal institutions.

An important contrast can be seen in the treatment of African American youths. Whereas there was universal support for bringing Christian education to Native peoples, there were intense disagreements over the merits of educating African children. Some feared that baptized slaves would claim the status of free men. Others warned that reading and writing would cause revolts. Some southern states made it a crime to teach literacy to slaves and passed laws announcing that conversions to Christianity would not change one's slave status. Eventually a middle course emerged that permitted religious training but banned the more dangerous education in reading and writing.

Social control among European colonists employed the family as the principal vehicle of restraint. Indentured youths owed their masters all the duties that children owed parents. European colonists were familiar with a network of institutions such as the English Bridewell, the Amsterdam House of Corrections, and the French hospitaux generaux designed to house the needy, the infirm, and the poor. These institutions were designed to instill disciplined work habits and to be financially self-sufficient. Inmate labor was contracted out, and some limited manufacturing was conducted in the facilities.

The next major development covered in Stubborn Children is the creation of the houses of refuge during the $1820 \mathrm{~s}$ - the first American specialized institutions for delinquents. Sutton argues that Calvinist-inspired reform organizations saw the refuges as one method by which an increasingly complex social order could be kept under control, thus conserving the status quo rather than changing it. Proposed initially to remove children from adult jails and workhouses, the refuges emerged with their own conceptions of rehabilitation. To gain political support to open the refuges, the Calvinists soon were required to integrate their conceptions with other ideologies stressing environmentalism and prevention. The educational and work components of the refuges responded to these concerns. The superintendents of the houses of refuge also promised to implement very modern conceptions of moral education. While these divergent views were temporarily harmonized, substantial disagreements among factions developed early in the operations of the houses of refuge. Sutton also notes that the refuge board of directors placed the highest value on security, consistency, and political legitimacy. This brought them into conflict with refuge superintendents, who often pursued more idealistic goals. In 
these struggles the superintendents were usually forced to accommodate the managers' wishes. Sutton makes a compelling case that larger societal forces forged a temporary alliance among ideologically distinct groups; this alliance would soon dissolve as the refuges began operation. The refuges coalition included religious conservatives, humanitarian visionaries, and social pragmatists. Immediate conflicts arose among these groups about how to handle escapes, institutional misconduct, and discipline.

The legal diffusion of the refuge movement preceded changes creating the new categories of delinquency, dependency, and neglect. According to Sutton, laws were enacted to fit the operational needs of the facilities rather than facilities being created to meet novel jurisprudential developments. Sutton's argument here includes a multivariate statistical analysis of the diffusion of these legal changes, focusing on structural factors such as immigration, manufacturing development, political formalization, and urbanization. Except for the effect of the Civil War, which slowed the expansion of reformatories in the southern states, the statistical analysis could not account for the diffusion of the reformatories. Sutton does report statistical data that links the development of reformatories closely to state efforts to expand educational systems.

Stubborn Children next shifts its attention to the creation of the juvenile court -250 years after the passage of the Stubborn Child Act. Sutton's most controversial conclusion is that the founding of the juvenile court served mostly ceremonial goals, since virtually all aspects of the separate legal status of juveniles were in place before the creation of the court. The new children's court was an extension of existing conceptions of the causes and cure of delinquent behavior. Sutton provides strong evidence that the new court represented the triumph of the principles of administrative control and bureaucratic rationality. He notes that the division of labor between judge and probation officer fulfilled the objective of increased management efficiency. The court provided a legally sanctioned place in which diagnostic and placement decisions could be made. However, the pool of available placements and sanctions was not materially altered. Sutton argues that the popular appeal of the new juvenile court was its close fit with the larger Progressive Era ideology.

The first juvenile courts were caught in a powerful conflict as they attempted to reconcile the need to punish offenders with the mandate to diagnose and treat. Sutton suggests that these imperatives are unreconcilable and the contemporary juvenile court remains enmeshed in this conflict.

Stubborn Children next discusses decarceration reforms of juvenile justice that began in the late 1960 s and traces the development of decarceration through the 1970s. He reviews the significance of the Gault decision, which greatly expanded children's rights in juvenile court, and the growing 
federal involvement in juvenile justice policy formulation with the passage of the Juvenile Justice and Delinquency Prevention Act (JDPA) of 1974, which required participating states to remove status offenders from secure confinement and to separate adults and juveniles in correctional facilities. The broader context for all of these events was a societal-level push toward decarceration of juvenile offenders.

Sutton argues that the enormous inertia of the juvenile justice system limited the potential impact of these far-reaching changes. The central tenets of court ideology - prevention, rehabilitation, and the maintenance of the family unit-were untouched by the decarceration movement. The primacy of the medical model of juvenile justice meant that advances in procedural justice were, at best, difficult to achieve. What did change was the ideology of informal court operations, which was limited to very minor offenders and nonoffenders. More serious youth criminals were treated more like adults.

Sutton finds that federal government activity was important to spreading the decarceration process, albeit in an uneven and incomplete way. In his words "the road to reform does not end in Washington, but runs through it." We also witness the shift from the outside critic to the professional as the major stimulus for change. Over time, Sutton concludes that the outside critic was replaced by the "insider" professional as the catalyst for change. Sutton finds little empirical support for the functionalist explanation that connected the decarceration movement with the "fiscal crisis" of state governments, although in my judgment, his data analysis does not adequately address the issue. In my own analysis of the "net widening" aspects of liberal reforms, I have argued that both material forces and bureaucratic struggles are needed to explain why diversion, deinstitutionalization, and decriminalization efforts have not worked. ${ }^{4}$

While Sutton's analysis of the decarceration movement is intriguing, it misses some crucial issues. For instance, data from the Children in Custody statistical series show that between 1974 and 1979 there was a dramatic drop in confinement of females but male juveniles were confined in higher numbers. Indeed, the decline in female incarceration accounts for virtually all the reduction in youth confinement during this period. Similarly, the decarceration movement exerted its greatest benefit for white females. There was no decline in Hispanic youth confinement, and only a small drop in the black female juvenile incarceration rate. These data lend strong support to Sutton's hunches about the dual nature of the decarceration process-informality for the less serious offender, criminal justice handling for the rest. Yet, the gender and racial outcomes cannot be interpreted purely in these terms.

4. Barry Krisberg \& James Austin, "Wider, Stronger and Different Nets: The Dialectics of Criminal Justice Reform," 18 J. Research Crime $\mathcal{E}$ Delinq. 165 (1981). 
Sutton's conclusions about the limited impact of federal government decarceration programs are correct. One reason for this result has to do with methods of financing reforms. In one study, I found no correlation between federal expenditures under the JJPDA and reductions in the numbers of youths in custody. ${ }^{5}$ Federal funds were distributed by a formula based on the size of the state's youth population. This is a politically attractive approach to guide a federal grant program, but it does not reflect the actual distribution of youth incarceration rates. A small number of states account for a vast majority of youths in custody. Thus, the blockgrant approach often supported decarceration efforts in states with very low rates of youths in custody.

Unfortunately, Sutton's analysis ends in 1981 and misses the major conservative retrenchment in juvenile justice during the Reagan years. Several of the trends Sutton describes were reversed (e.g., incarceration rates began rising, even for females and white males) and the ideology of punishment gained preeminence among many juvenile justice practitioners.

Stubborn Children closes with a theoretical argument that tries to update and specify the Weberian sociology of law. The relevance of this exegesis to contemporary reform seems obscure to this reader.

Sutton offers a pessimistic outlook on the prospects for genuine justice for children. He notes the resilience of the status quo ideology over hundreds of years of reform. Sutton also correctly identifies the class conflict inherent in the reform process. The clients of juvenile justice are "other peoples' children," and we respond to them with less sympathy and compassion than we give to our own progeny. However, Sutton offers no apparent way out of the continued inferior care of troubled children. This tragic view of life, long popular in academic circles, fails to consider sweeping and dramatic institutional changes that have occurred in many sectors of American life. It may well be that Sutton's focus on the ideological struggles of the elite blinds him to the genuine victories that are possible. He spends little time understanding such small successes as the closing of the Massachusetts and Utah training schools. ${ }^{6}$ Even isolated examples of progress can point future directions for concerted social action. ${ }^{7}$

Sutton's view also is limited by the exclusive focus on juvenile justice. During the same period, the adult justice system was transformed, albeit in (1983).

5. Barry Krisberg \& Ira Schwartz, "Rethinking Juvenile Justice," 29 Crime $\mathcal{E}$ Delinq.

6. These states completely closed their large juvenile correctional facilities. Both jurisdictions confine a very few youths in small, secure facilities. The majority of juvenile offenders in Utah and Massachusetts are managed in community-based programs.

7. John Blackmore, Marci Brown, \& Barry Krisberg, Juvenile Justice Reform: The Bellwether States (Ann Arbor: Center for the Study of Youth Policy, University of Michigan, 1988). 
a destructive and mean-spirited direction. We need to explain the continued public faith in treatment and rehabilitation of youths in a era in which the Calvinist ideology reemerged for adult offenders.

\section{JUVENILE JUSTICE REFORM: THE CONTEMPORARY SCENE}

Ira Schwartz has written an engaging and thoughtful analysis of the dilemmas faced by modern day juvenile justice reformers. The book, written by one of America's leading child advocates, examines the last two decades of juvenile justice reform. As former administrator of the federal Office of Juvenile Justice and Delinquency Prevention (OJjDP), Schwartz has a unique vantage point from which to view the contemporary juvenile justice scene.

An attractive part of (In)justice for Juveniles is the combination of behind-the-scenes storytelling and political analysis of broader trends. In the opening chapter "While the Reformers Slept," Schwartz vividly tells how the progressive Washington-based reformers and prestigious national groups were out of touch with developments in the states. For instance, in the late 1960s national commissions were warning of the rising tide of juvenile crime and the need to avoid overcrowded training schools. In fact, during this period states were attempting to close down correctional beds and divert youngsters to community-based programs. By the middle 1970s when federal officials were espousing the goals of deinstitutionalization, the states were beginning a renewed crackdown on youthful criminals, passing harsher juvenile sentencing laws. The Reagan administration found itself advocating the "get tough" approach just as several states were seeking to reduce the numbers of incarcerated juveniles. Schwartz's point is that professional reform groups and Washington-based activists (whether conservative or liberal) are operating on information and values that significantly lag behind state practices. Since the organization of juvenile justice is so decentralized, this trend should not be surprising. Schwartz does not view the road to reform as going through Washington; rather, the nation's capital is usually the last exit for reform ideas.

Schwartz also argues that under the guise of juvenile justice, reformers have a tendency to ignore the continuing abuses and maltreatment of children. Swept up in the nobility and optimism of reform, many professionals forget the intractable shortcomings of current practices. It is important to juvenile justice workers that their image as professionals not be eroded by revelations of cruel and unfair practices. Schwartz notes that litigation to obtain basic decency and legality in juvenile corrections reveals the gap between rhetoric and reality, as tremendous abuses are revealed in jurisdic- 
tions that publicly espouse their concern for child protection. Indeed, the cycle of abuse and scandal, outrage and reform, followed by a return of abusive practices seems to fit the history of American juvenile justice.

Juvenile crime is clouded by dangerous myths. Schwartz does an excellent job of identifying the most insidious falsehoods and providing data to refute them. This information disconnection makes juvenile justice policy easy prey for demagogues of every political stripe. For example, the public overrates the extent and seriousness of juvenile crime. Even as the number and rate of juvenile arrests were dropping, public opinion polls report citizen views that youth crime was climbing at an alarming rate. ${ }^{8}$ While these data might also be explained by more laxity in law enforcement policies, the early 1980s aggressive police policies were the norm. The public incorrectly assumes that young people are the chief victimizers of the elderly. ${ }^{9}$

The citizenry get these views from distorted media accounts and the hyped rhetoric of politicians and justice system officials. Some of the most corrosive myths portray youth crime as exclusively a minority problem and more violent than adult criminality. There are such other public falsehoods as that juvenile courts are too lenient with violent youths, that female violent crime is out of control, and that violent criminals are younger than ever before. Myths justify popular get-tough legislation and build support for bigger agency budgets. Public hysteria over isolated instances of youth violence (e.g., a vicious assault of a jogger by teenagers in New York's Central Park) leads to symbolic political responses.

Schwartz offers the reader some brief profiles of successful and failed efforts to reform juvenile justice practices nationwide. Although he does not offer an elegant sociological framework, his cautionary tales are suggestive. For Schwartz the key factor is political leadership. Are the politicians prepared to move beyond empty rhetoric toward more humane and enlightened practices? The research evidence points to more productive methods of handling youthful criminals. The key question is whether professionals and elected officials are courageous enough to demystify the juvenile crime situation for their constituents.

The movement to end the jailing of children is one of the most successful reform efforts in recent years. Schwartz was the principal architect of federal legislation to ban the jailing of children. The 1980 amendments to the JJDPA gave states five years to effect the total removal of juveniles from jails and police lockups. Progress toward this goal has been signifi-

8. David Steinhart, Califomia Opinion Poll: Public Attitudes Towards Youth Crime (San Francisco: National Council on Crime and Delinquency, 1988).

9. Data on public perception and its falsity are reported in Bureau of Justice Statistics, Report to the Nation on Crime (Washington, D.C.: Government Printing Office, 1988). 
cant, albeit not universal. Nationally, the jailing of juveniles appears to have declined from approximately 500,000 per year to less than 100,000 .

Consistent with Schwartz's other observations, the jail removal movement began in the states, most notably Texas and Pennsylvania. Jail removal represented one example in which federal and state reform agendas were briefly aligned during the last year of the Carter administration. The passage of federal legislation that was strongly endorsed by top officials in the U.S. Justice Department provided a major stimulus for further state action. Even though strong federal enforcement actions have not materialized, the 1980 amendments strengthened the arguments of local child advocates and gave the childien's rights lawyers new tools in the courtroom. For instance, in California the Youth Law Center and the National Council on Crime and Delinquency ( $\mathrm{NCCD}$ ) mounted a victorious statewide campaign to legislatively ban the jailing of children in California. The Youth Law Center used the JJDPA as a legal argument, and NCCD promoted the experiences of states that were in compliance with the federal requirements.

Schwartz points out that much more needs to be accomplished to end the pernicious practice of jailing children. He offers compelling data from Minnesota to illustrate how young, minor offenders continue to be admitted to adult facilities in a state admired nationally for its progressive child welfare system. Although there is a strong political and professional consensus to remove juveniles from jails, the inertia of juvenile justice described by Sutton remains a powerful force. However, the major strides forward in jail removal, both politically and programmatically, require more complete analysis as a guide to achieving other reform goals.

In its most controversial chapter, (In)justice for Juveniles discusses the record of major child advocate organizations. In Schwartz's words, "with friends like these, who needs enemies?" In particular, Schwartz tells of the self-serving actions of leading groups in the juvenile justice field, who have become preoccupied with obtaining major federal discretionary grants. There are interesting stories of how several of these groups maneuvered to win the favor of the more conservative Reagan officials who took over the OJjDP. While this juicy gossip is fun reading, particularly for those who already are cynical about professional groups, I am not sure that understanding of interest group politics is advanced. As Sutton pointed out in Stubborn Children, reformers constantly had to accommodate diverse interest groups to effect their objectives. Part of the accommodation process entails building political and financial support for one's organization. Schwartz provides ample data to support Sutton's thesis that insiders or professionals emerged as the principal juvenile justice reformers.

According to Schwartz, there are heroes for children who match the villains. He singles out a number of individuals and legal organizations 
that have toiled persistently to advance the decent care of delinquent youths. The Massachusetts Advocacy Center, Kentucky Youth Advocates, the Florida Center for Children and Youth, and the NCCD are briefly described by Schwartz as exemplars of long-term commitments to the struggle for youth rights. Schwartz pays special homage to Jerome Miller who, as an administrator, closed all Massachusetts training schools in the early 1970s. Miller continued his reform efforts in Pennsylvania and, somewhat less successfully, in Illinois. He remains an inspirational figure for contemporary child advocates.

One of the most interesting sections of (In)justice for Juveniles covers the federal role in juvenile justice policy. Here Schwartz gives us an insider's view of the politics of the JJDPA of 1974 and the subsequent assault on the law by the Reagan administration. Detailed are the ways in which federal officials played fast and loose with the data on youth crime and the political invention of the "missing child." Federal officials poured millions of dollars into programs to prevent child abductions. In fact, few missing children are taken by strangers-most are runaways or are abducted by a noncustodial parent. However, the public image was of an epidemic of criminal kidnapping.

There are several ways in which the federal juvenile justice program can be improved. It is urged that the block grants to states be expanded as an incentive for jurisdictions to improve their juvenile justice practices. Schwartz urges that states should be mandated to provide constitutional conditions of care for youth. He suggests that $80 \%$ of funding be awarded on a competitive basis to limit the abuses of recent ojjDP administrations, and that congressional oversight over oJjDP be strengthened. Other needed improvements in the federal program would involve activating the potentially powerful Coordinating Council on Juvenile Justice and Delinquency Prevention. The Coordinating Council, chaired by the Attorney General, consists of representatives of all cabinet-level departments concerned with youth and is theoretically charged with review and coordination of all federal juvenile delinquency policies, programs, and resources. Such a group could wield great influence and greatly reduce the current overlapping and contradictory federal programs in the youth area.

Schwartz covers a number of other topics related to the sorry state of juvenile justice. He discusses the growth of private adolescent chemical dependency and psychiatric programs, detailing the abusive practices aimed at the wayward children of the middle class and exploring the role of private insurance in perpetuating these abuses. He laments thexontinuing failure to provide adequate legal representation for indigent youths, noting that without sufficient legal assistance the rights guaranteed under Gault are little more than ceremonial shams. (In)justice for Juveniles offers an exciting agenda for advancing the concept of justice for young people. 
Schwartz urges that the juvenile court provide all the legal safeguards available to adults-even expanding them to include an irrevocable right to counsel for youths; he urges that court proceedings be opened to public scrutiny and that juvenile probation services be completely overhauled.

Schwartz shares Sutton's pessimistic view of the future of juvenile justice. Both see juvenile justice as circumscribed by social, economic, and political forces in the larger society. Both authors note the seeming inability of professionals to change bad practices, and both point to the inherent contradictions of pursuing justice alongside the therapeutic model of the juvenile court. In addition, Schwartz points to the growing number of children growing up in poverty. He warns us that labor market changes are making escape virtually impossible from society's economic bottom. Profound changes in families and migration patterns also shape the future faced by our children.

\section{CAN JUSTICE FOR JUVENILES BE ACHIEVED?}

The history of American juvenile justice is not a slow march toward more enlightened and compassionate care of children. For both Sutton and Schwartz, this history is one surrounded by the reality of ideology and of interest-group politics. In Jerome Miller's terms, we have witnessed a revolution in rhetoric, not action. The ascendancy of juvenile justice professionals as the primary change agents makes genuine reforms unlikely.

Some observers argue that juvenile justice should be abandoned. ${ }^{10}$ This approach would certainly solve some problems but would generate other concerns. Children, after all, are not simply small adults. Any social policy that ignores that fact is destined to failure. Put differently, juvenile justice must incorporate a genuine developmental perspective into all its functions. This developmental viewpoint should be based on solid research, not political demagoguery (recall the Central Park case) or plea bargaining.

Justice for children seems unlikely if the legal apparatus is chronically underfinanced and relies on barely trained personnel. The juvenile court does not possess great prestige in the legal world; it does not draw the best judges, prosecutors, and defense attorneys. Resources and options for dispositions are far too narrow. The ideal of diagnosis and treatment assumes a broad range of diverse programs and interventions. Such states as Massachusetts, Maryland, and Utah have learned that closing the traditional training schools can free up funds, personnel, and, most important, imagination to create innovative programs for troubled youths. These new in-

10. Marvin Wolfgang, "Abolish the Juvenile Court," Cal Law., Nov. 1982, at 12-13. 
terventions include specialized group homes, day treatment programs, wilderness programs, and intensive supervision programs.

Today the juvenile court is under siege. Critics of the left and right doubt the value of a separate justice system for young people. Court rooms, detention centers, and training schools are jammed with children and families swept up by the cruel realities of extreme poverty and drug abuse. Related child-welfare and educational programs are also in deep financial and administrative turmoil. Federal leadership on juvenile justice matters is nonexistent.

It is important to ask: Where do we go from here? This essay has reviewed two excellent monographs on how we arrived at the current nearcollapse of juvenile justice. One lesson is the limitation of "top-down" reform strategies, especially those designed and orchestrated by professionals. However, the prospects for a grassroots approach to reform seem at best unclear. The task of modern reformers is to garner compassion and political support for improving the treatment of disadvantaged young people. Increased litigation is one way to compel the attention of public officials to the plight of mistreated juveniles. But lawsuits must be combined with politically astute public education efforts that are designed to market solutions to rectify constitutional deficiencies.

It took years of congressional hearings and lobbying to enact the JJPDA of 1974. Despite the early promise of that legislation, eight years of national conservative political domination has virtually gutted the key components of that program. Child advocates may have no choice but to begin again the long march through state legislatures and to Washington to recapture the lost juvenile justice agenda. 
HeinOnline -- 15 Law \& Soc. Inquiry 9061990 